\title{
Effeciency of Degreasing / Settling Tank Followed by Constructed Wetland for Greywater Treatment
}

\author{
H. I. Abdel-Shafy and A. M. Al-Sulaiman* \\ Water Research \& Pollution Control Department National \\ Research Centre, Dokki, Cairo, Egypt and *Faculty of \\ Engineering, Civil Department, Ministry of Higher Education \\ \& Scientific Research, Qadisiyah University, Iraq.
}

THE PRESENT study deals with real greywater. The objective of this study is to investigate the treatment of greywater for the purposes of reuse. Greywater treatment was examined first to determine the optimum degreasing / settling time. Further treatment by hybrid constructed wetland was examined. Efficient removal of the pollutant parameters was achieved. The experimental method involves evaluation of the treated effluent to reach the allowable limits of water reuse according to "Egyptian Environmental Association Affair, EEAA". Final removal rates reached $87 \%, 83 \%, 88 \%, 91 \%$, $36 \%, 92 \%$, and $58 \%$ for the TSS, COD, $\mathrm{BOD}_{5}, \mathrm{TP}, \mathrm{NO}_{3}$, oil \& grease and TKN, successively. The E. coli count and the number of cells or eggs of Nematode in the final effluent reached $100 / \mathrm{ml}$ and " $1 \mathrm{egg} / \mathrm{L}$ ", respectively.

Keywords: Sewage separation, Degreasing, Settling, Hybrid constructed wetlands and Greywater treatment .

Most of the Arab countries are located in arid and semi-arid zones known for their scarcity of annual rainfall, very high rates of evaporation and consequently extremely insufficient renewable water resources. Sustainable management of water resources is a must, as water scarcity is becoming more and more constraint impeding the economic growth of many countries in the region ${ }^{(1-3)}$

Sustainable water management strategies are considered to be the key solutions to cope with the issues of shortage of water and reuse ${ }^{(2)}$. The increasing water shortage reported over the past decade is caused primarily by the growing population combined with lifestyle changes, especially in urban areas. This result leads to increase the conflict between agricultural and other water uses. Sustainable management is currently becoming a dominating approach, focusing on long-term research objective of closed loop recycling. To close between demand and supply, non-conventional water resources have to be developed. One

*Email:ahmed_makki2002@yahoo.com 
of these resources is domestic wastewater. Hence, reclaimed wastewater is an interesting non-conventional resource to reduce water shortage especially in arid $\operatorname{areas}^{(3)}$.

Greywater is defined as wastewater without any input from toilets or heavily polluted industrial wastewater and generally includes sources from baths, showers, hand washing basins, washing machines, dishwashers and kitchen sinks ${ }^{(4)}$. Municipal wastewater separation into black and greywater proved to be an efficient system to prevent the contamination of greywater, reduce the volume of fecal contaminated wastewater as well as eliminating the cost of treatment ${ }^{(1)}$.

On-site greywater reuse has the potential to play a significant role. Some technologies such as membrane bioreactors "MBR" or sequencing batch reactors "SBR" have demonstrated the capacity to produce high quality treated effluent ${ }^{(5,6)}$. Most greywater treatment systems installed are based on degreasing tanks in combination with constructed wetlands ${ }^{(7,8)}$. However, cost, application to scale and the relatively low public perception may limit their application in small communities especially in rural areas of developing countries "arid and semi-arid regions".

In urban areas the most feasible greywater reuse option is for toilet flushing, which can reduce individual in-house net water demand by 40-60 L/d PE. If this practice becomes widespread, reduction of 10-25\% in urban water demand can be achieved. For example, $30 \%$ of houses having greywater reuse units installed, greywater reuse for toilet flushing in the domestic sector could save about 50 $\mathrm{MCM} / \mathrm{y}$ in Mediterranean countries ${ }^{(9)}$. Additionally, greywater contains low nutrients concentrations, ranging from 5 to $22 \mathrm{mg} / \mathrm{l}$ of total nitrogen and 0.2 to $3.9 \mathrm{mg} / \mathrm{l}$ of total phosphorus, an easily biodegradable organic content and a relatively low pathogens content ${ }^{(10)}$. For these reasons, greywater is much easier to treat and safer to recycle for water usages that do not need potable water quality, such as toilet flushing, urban landscaping or road washing.

In such communities, simple low-tech and efficient systems, such as constructed wetlands "CW", may be more appropriate. CWs treatment can be defined as a man-made, engineered wetland area specifically designed for the purpose of treating wastewater by optimizing the physical, chemical and biological processes that occur in natural wetland ecosystems. $\mathrm{CW}$ can provide economical on-site wastewater treatment that is both effective and aesthetically pleasing $^{(11)}$.

A wide spectrum of technologies, from very simple to sophisticated systems, can be utilized for greywater treatment and reuse ${ }^{(12)}$. The greywater treatment needs both physical and biological processes for removal of particles, dissolved organic-matter and pathogens ${ }^{(13)}$. Recently, many researchers have studied the greywater treatment either by application of high-rate aerobic systems, such as the rotating biological contactor, fluidised bed ${ }^{(11)}$, or by application of low-rate systems, like "slow sand filter"(13). Most of the time, the wetlands can be Egypt. J. Chem. 57, No. 5, 6 (2014) 
constructed with local materials which lowers the construction cost significantly. Furthermore, these treatment systems are good at removing not only pathogenic and nutrients but also toxic metals and organic pollutants ${ }^{(14)}$. Further investigations for the treatment of greywater for the purpose of reuse were carried out by many authors ${ }^{(15,16)}$.

\section{Objective of this Study}

The present study focuses on the treatment of greywater by the degreasing / settling process followed by hybrid constructed wetland "constructed wetland horizontal flow (CWHF) and constructed wetland vertical flow (CWVF)" as simple, low cost, low energy and friendly techniques for the urban and decentralized areas. The experimental method involves monitoring of specific greywater constituents under varying operating conditions in the different degreasing / settling periods followed by the hybrid constructed wetland for assessing the water quality produced from such system.

\section{Material and Methods}

Sources of raw greywater

Municipal wastewater is separated into Black "B" and Grey "G" water segregated and collected from one building across the Training Demonstration Centre "TDC" site in the National Research Centre "NRC", Cairo, Egypt. This building consists of two separated sides. Each side consists of five apartments. One side is presently connected to the TDC site as separated B and G water manholes. The collected greywater "G" is the subject of the present study. It includes wastewater from baths, showers, hand wash basins, washing machines, dishwashers and kitchen sinks.

Analytical and measurement for greywater

The physical and chemical characteristics of the raw greywater were determined on weekly basis. Meanwhile, the physical and chemical characteristics of the examined greywater before and after degreasing/ settling tank as well as before and after the hybrid constructed wetland through all the study were carried out according to the American Public Health Association "APHA" (17).

\section{System configuration}

The pilot plant

Two-step successive degreasing / settling tanks were constructed as a pretreatment to remove oil \& grease, larger particles, and hair. The effluent from the settling tanks was then fed into the hybrid constructed wetland tanks (CWHF and CWVF). The schematic diagram of the treatment systems is shown in Fig. 1. 


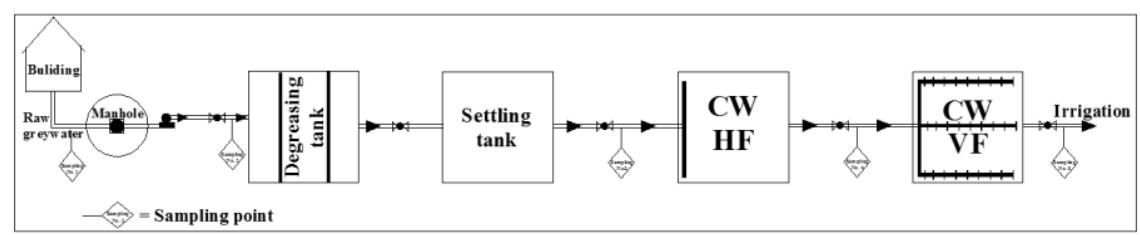

HF = Horizontal Flow,$\quad$ VF $=$ Vertical Flow,

Fig. 1. Schematic diagram of the treatment system.

\section{Degreasing / settling tank}

The degreasing / settling tanks are made of polyvinyl chloride "PVC" with a capacity of $0.7 \mathrm{~m}^{3}$ each. The dimensions of each tank are: $1.00 \mathrm{~m}$ height, $0.90 \mathrm{~m}$ width and $1.00 \mathrm{~m}$ length. The reactor is a rectangular basin raised from the ground surface about four meters. The first tank (degreasing) consists of three chambers $0.3 \mathrm{~m}$ in length, $0.9 \mathrm{~m}$ in width and $1.00 \mathrm{~m}$ in depth separated with baffles at the dimensions of $0.4 \mathrm{~m}, 0.3 \mathrm{~m}$. The outlet is then directed to the second tank (settling). These chambers provide the undisturbed area necessary for settling. The detail of settling tank is shown in Fig. 2. The flow rate of the greywater influent to the settling tank is 225 liters/ hr with Surface Overflow Rate "SOR" about 2.5 meter /hour, and the retention time of $1.5 \mathrm{hr}$. The examination of the removal efficiency was undertaken at different settling times; $1.5,3.0$ and $4.5 \mathrm{hr}$.

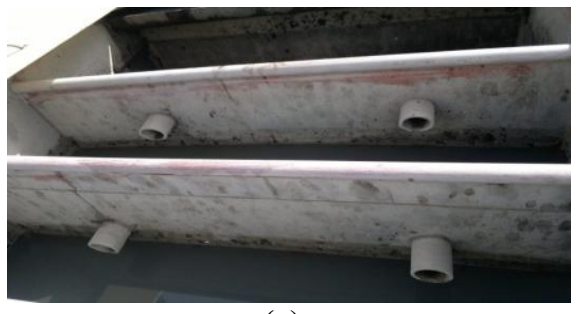

(a)

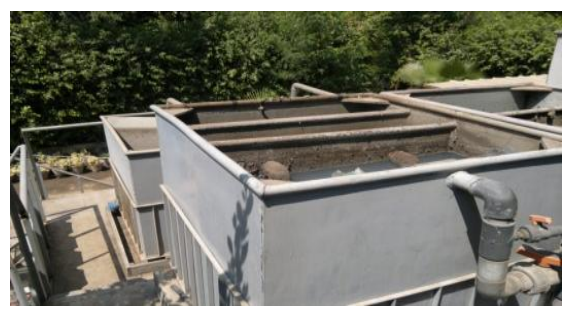

(c)

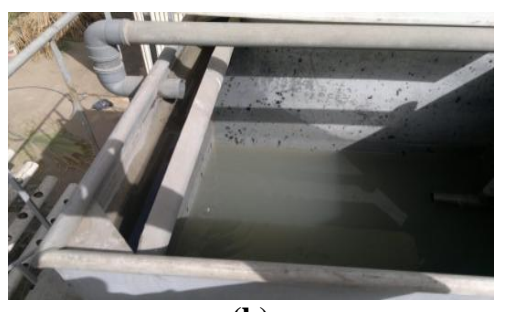

(b)

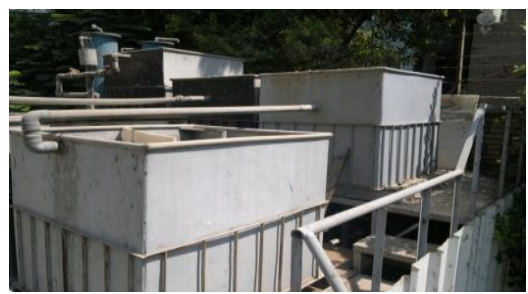

(d)

Fig. 2. Degreasing tank followed by settling tank.

$\begin{array}{ll}\text { (a) Degreasing tank (top view) } & \text { (b) Settling tank (top view) }\end{array}$
(c) Degreasing and settling tank (top view)
(d) Degreasing and settling tank (side view)

Egypt. J. Chem. 57, No. 5, 6 (2014) 
Constructed wetland unit

The design and operating conditions for the treatment of the greywater through the constructed wetland are represented in Table 1.

TABLE 1. Dimensions and operating conditions of the constructed wetland for greywater.

\begin{tabular}{|c|c|}
\hline \multicolumn{2}{|c|}{ Dimensions and Materials } \\
\hline No. of units & 2 \\
\hline Length & $1.2 \mathrm{~m}$ \\
\hline Width & $1 \mathrm{~m}$ \\
\hline Water depth & $0.50 \mathrm{~m}$ \\
\hline Plant & Phragmittes austeralis \\
\hline No. of rhizomes / $\mathrm{m}^{2}$ & 3 \\
\hline Substrate & $\begin{array}{c}\text { Sand }(0.20 \sim 0.45) \mathrm{mm} \text {, Rice straw }\left(15 \mathrm{~kg} / \mathrm{m}^{3}\right), \\
\text { and Small gravel }(0.5 \sim 1.0) \mathrm{mm}\end{array}$ \\
\hline Metal piping inlet and outlet & PVC \\
\hline \multicolumn{2}{|c|}{ Operalve } \\
\hline Release and retain greywater & $2.2 \mathrm{~d}$ \\
\hline Hydraulic retention time (HRT) & $430 \mathrm{~m}^{3} / \mathrm{ha} . \mathrm{d}$ \\
\hline Hydraulic loading rate (HLR) & $271 \mathrm{~kg} \mathrm{BOD} / \mathrm{ha} / \mathrm{d}$, \\
\hline Organic loading rate (OLR) & $356.4 \mathrm{~kg} \mathrm{COD} \mathrm{ha/d}$ \\
\hline
\end{tabular}

The Vascular plant of the constructed wetlands

'Phragmites australis' or "Reed Grasses" as the common reeds in Egypt was namely used as the main plant in the constructed wetland. The rhizomes were collected from a near-by marshland, washed several times with distilled water prior to use and planted at the density of 3 rhizomes $/ \mathrm{m}^{2}$.

\section{Substrate of $C W$}

The constructed wetland unit was fed continuously with the effluent of settling tank. The wetland unit was manufactured from non-transparent PVC. The substrate was arranged in three layers: sand, rice straw and gravel. The average granular size for sand used in the experimental work is $0.35 \mathrm{~mm}$, height $10 \mathrm{~cm}$, the average height of rice straw about $15 \mathrm{~cm}$, density $15 \mathrm{~kg} / \mathrm{m}^{3}$, and the average granular size for gravel is $0.75 \mathrm{~mm}$ and height of $25 \mathrm{~cm}$.

Calculations of hydraulic retention time "HRT" and organic loading rate "OLR" Calculation of flow rates and HRT of wetlands was based on the following equation $^{(18)}$

$$
Q=\left(A^{*} d^{*} \eta\right) / t
$$

where:- $\mathrm{Q}=$ discharge flow $\left(\mathrm{m}^{3} /\right.$ day $)$,

$A=$ surface area $\left(\mathrm{m}^{2}\right)$

$d=$ water depth of the system $(\mathrm{m})$, $t=$ detention time (day)

by substituting in the equation: $\mathrm{t}=((1.2 * 1.0) * 0.5 * 0.4) / 0.11$

then, (HRT) was 2.2 days

Meanwhile,

$$
O L R=\left(C^{*} d^{*} \eta\right) / t
$$


where:- $O L R=$ organic loading rate $(\mathrm{kg} \mathrm{BOD} / \mathrm{ha} / \mathrm{day}), \quad C=\mathrm{BOD}$ concentration of the influent $(\mathrm{mg} / \mathrm{l}), d=$ water depth of the system $(\mathrm{m}), \quad \eta=$ porosity of the system, $t=$ detention time (day) Then, OLR was $270.91 \mathrm{~kg} / \mathrm{BOD}_{5} /$ ha $/$ day

\section{Description of the treatment system}

The constructed wetland associated in the biological treatment had elements of aeration and plants. The biological treatment is within the aerobic bacterial growth. These bacteria grew naturally and were responsible for decomposition of suspended/ dissolved organic matter. Finally, this treated greywater was then available for gardening purposes from and to enhance the biodegradation of any organic contamination. The Hydraulic Retention Time "HRT" of the system was 3 days, as was shown in Fig. 1.

The constructed wetland is consisted of two series with a retention time of three days. Subsurface horizontal flow "HF" and subsurface vertical flow "VF" systems have different advantages. Two stage HF-VF hybrid systems achieve good removal of $\mathrm{BOD}_{5}, \mathrm{COD}$ and TSS but not total nitrogen because of low denitrification in the last VF stage ${ }^{(19)}$. Starting a hybrid $\mathrm{CW}$ with a horizontal bed system means that $\mathrm{BOD}_{5}$ will be removed and prevented from interfering with nitrification in the vertical flow stage. Each series consists of three beds, one planted with reed, rice straw and sand with gravels. Each wetland bed was 0.6 $\mathrm{m}^{3}$; with $0.75 \mathrm{~mm}$ average diameter of small gravel as a supporting medium. A plastic basin was placed for this study to prevent water contamination. An inlet and outlet zone, each $20 \mathrm{~cm}$ width, consisting of medium gravel $1 \sim 2.5 \mathrm{~mm}$ diameter, was used to eliminate the effects of the inlet and outlet. Each bed had a polyvinyl chloride "PVC" inlet pipe at its top, ending with horizontal drainage pipe, $50 \mathrm{~mm}$ diameter. The influent into each bed was controlled every day by measuring the flow rate and adjusting the valve to maintain a continuous daily flow rate. The schematic diagram of $\mathrm{CW}$ is shown in the Fig. 3.

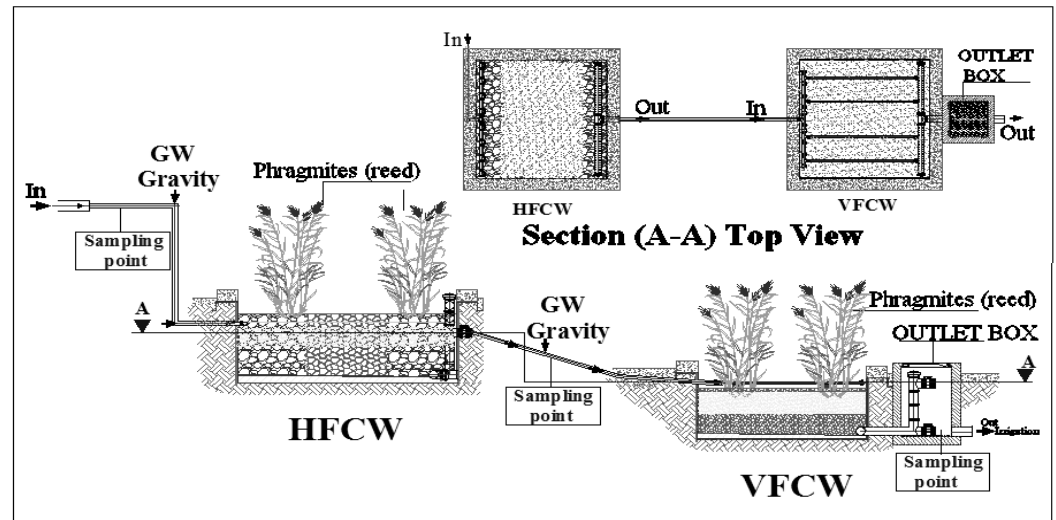

Fig. 3. Schematic diagram of hybrid constructed wetland treatment system. 


\section{Results and Discussion}

Characteristics of raw greywater

The characteristics of the raw greywater are given in Table 2. The analysis showed that the concentration of physical, biological and microbiological parameters are within the medium levels.

TABLE 2. Characteristics of raw greywater.

\begin{tabular}{|c|c|c|c|c|}
\hline Parameter & Unit & $\begin{array}{l}\text { Min. } \\
\text { value }\end{array}$ & $\begin{array}{l}\text { Max. } \\
\text { value }\end{array}$ & Average \\
\hline $\mathrm{pH}$ & --- & 5.75 & 7.91 & 6.65 \\
\hline Electrical Conductivity (EC) & $\mathrm{ms} / \mathrm{cm}$ & 522 & 904 & 682 \\
\hline Temperature & ${ }^{\circ} \mathrm{C}$ & 24.51 & 28.81 & 26.88 \\
\hline Total Suspended Solids (TSS) & $\mathrm{mg} / \mathrm{L}$ & 55 & 131 & 90 \\
\hline Chemical Oxygen Demand (COD) & $\mathrm{mg} \mathrm{O}_{2} / \mathrm{L}$ & 297 & 523 & 387 \\
\hline Biological Oxygen Demand $\left(\mathrm{BOD}_{5}\right)$ & $\mathrm{mg} \mathrm{O}_{2} / \mathrm{L}$ & 145 & 388 & 293.4 \\
\hline Total Phosphates (T. P.) & $\mathrm{mg} / \mathrm{L}$ & 8.4 & 11.8 & 10.42 \\
\hline Nitrates $\left(\mathrm{NO}_{3}\right)$ & $\mathrm{mg} / \mathrm{L}$ & 0.39 & 0.48 & 0.40 \\
\hline Total Kjeldahl Nitrogen (TKN) & $\mathrm{mg} / \mathrm{L}$ & 17 & 29 & 27 \\
\hline Oil \& Grease & $\mathrm{mg} / \mathrm{L}$ & 92 & 155 & 115 \\
\hline $\begin{array}{l}\text { Adjusted Sodium Absorption Ratio } \\
\left(\mathrm{SAR}_{\mathrm{adj}}\right)\end{array}$ & $\%$ & 19.22 & 33.05 & 23.15 \\
\hline Number of cells or eggs of Nematode & $\mathrm{Egg} / \mathrm{L}$ & ND & 1 & --- \\
\hline E.coli count & $100 / \mathrm{ml}$ & ND & $<100$ & --- \\
\hline
\end{tabular}

$\mathrm{ND}=$ Not detected, Min. $=$ minimum, Max. $=$ maximum.

\section{Degreasing / settling tank}

The examined settling times were 1.5, 3.0 and $4.5 \mathrm{hr}$. Results indicated that the longer the settling time is, the highest reduction of pollution parameters is (Table 3). At the settling time $3.0 \mathrm{hr}$, greywater removal efficiencies reached $65.1 \%, 17.0 \%, 18.5 \%$ and $24.4 \%$ for the TSS, COD, $\mathrm{BOD}_{5}$ and oil \& grease, respectively. By increasing the settling time to 4.5 hr, better removal efficiency could be achieved namely; 66.5\%, 40.3\%, $38.5 \%$ and $50.2 \%$, successively. TSS results reported the best achieved removal parameter figures, namely $55.9,65.1$ and $69.77 \%$ at $1.5,3.0$ and 4.5 hr settling time, respectively. It is worth noting that the oil \& grease parameter was mostly removed after $4.5 \mathrm{hr}^{(20)}$. 
TABLE 3. Effect of different settling times on the average characteristics of raw GW.

\begin{tabular}{|c|c|c|c|c|c|c|c|}
\hline \multirow{3}{*}{ Parameter } & \multirow{3}{*}{$\begin{array}{c}\text { Raw } \\
\text { Grey } \\
\text { water }\end{array}$} & \multicolumn{6}{|c|}{ Settling Time } \\
\hline & & \multicolumn{2}{|c|}{$1.5 \mathrm{hr}$} & \multicolumn{2}{|c|}{$3.0 \mathrm{hr}$} & \multicolumn{2}{|c|}{$4.5 \mathrm{hr}$} \\
\hline & & $\begin{array}{c}\text { Con. } \\
\text { (Average) }\end{array}$ & $\% \mathbf{R}$ & $\begin{array}{c}\text { Con. } \\
\text { (Average) }\end{array}$ & $\% \mathbf{R}$ & $\begin{array}{c}\text { Con. } \\
\text { (Average) }\end{array}$ & $\% \mathbf{R}$ \\
\hline Temperature ${ }^{\circ} \mathrm{C}$ & 24.93 & 24.80 & --- & 25.1 & --- & 24.9 & --- \\
\hline $\mathrm{pH}$ & 7.63 & 6.59 & --- & 6.82 & --- & 6.85 & --- \\
\hline $\mathrm{EC}(\mathrm{ms} / \mathrm{cm})$ & 906 & 840 & 7.30 & 781 & 13.80 & 773 & 14.70 \\
\hline $\mathrm{TSS}(\mathrm{mg} / \mathrm{L})$ & 137.53 & 60.60 & 55.94 & 55 & 60.00 & 40 & 70.91 \\
\hline $\mathrm{COD}\left(\mathrm{mgO}_{2} / \mathrm{L}\right)$ & 464 & 397 & 14.44 & 385 & 17.03 & 277 & 40.30 \\
\hline $\mathrm{BOD}_{5}\left(\mathrm{mgO}_{2} / \mathrm{L}\right)$ & 390 & 348 & 10.77 & 318 & 18.46 & 240 & 38.46 \\
\hline TDS (mg/L) & 547 & 468 & 14.44 & 460 & 15.90 & 373 & 31.81 \\
\hline Oil \& Grease $(\mathrm{mg} / \mathrm{L})$ & 254 & 225.3 & 11.29 & 192 & 24.41 & 126.5 & 50.19 \\
\hline
\end{tabular}

$\% \mathrm{R}=$ Percentage of removal, Con. $=$ concentration

\section{Degreasing / settling as pretreatment followed by CWHF}

The settling time of the greywater was $3.0 \mathrm{hr}$. Results in Table 4 showed that the settling process achieved reasonable removal of TSS, COD, $\mathrm{BOD}_{5}$ and oil \& grease at the rate of $64 \%, 30 \%, 28 \%$ and $37 \%$, respectively.

The effluent was subjected to CWHF for $24 \mathrm{hr}$. The results obtained showed remarkable removal reached $81 \%, 56 \%, 49 \%$ and $73 \%$ for the TSS, COD, $\mathrm{BOD}_{5}$ and oil \& grease, respectively, (Table 4). It can be concluded that the COD, $\mathrm{BOD}_{5}$ and oil \& grease, except TSS are still over the permissible level of $2^{\text {nd }}$ group, "secondary wastewater treatment" for irrigation reuse according to Egyptian Guideline ${ }^{(21)}$.

Degreasing / settling as pretreatment followed by the hybrid system (CWHF and $C W V F$ )

The settling time of the greywater was $3.0 \mathrm{hr}$ and the effluent was subjected to the constructed wetland for $24 \mathrm{hr}$. The results obtained showed remarkable removal reached $87 \%, 83 \%, 88 \%$ and $92 \%$ for the TSS, COD, $\mathrm{BOD}_{5}$ and oil \& grease, respectively, (Table 4). However, the characteristics of the TSS, COD, $\mathrm{BOD}_{5}$ and Oil \& Grease were $16.17,77.5,39.83$ and $9.76 \mathrm{mg} / \mathrm{l}$, respectively. It is worth noticing that the characteristics of this final effluent are within the permissible level of $2^{\text {nd }}$ group, "secondary wastewater treatment" for irrigation reuse according to Egyptian Guideline ${ }^{(21)}$. 
TABLE 4. Main characteristics of raw greywater, effluent of degreasing/settling tank, effluent of horizontal wetland, and the effluent of the vertical wetland as well as removal efficiency of each treatment step. [The standard division is given between brackets].

\begin{tabular}{|c|c|c|c|c|c|c|c|c|c|c|}
\hline Parameter & TSS & COD & BOD $_{5}$ & SAR & $\mathbf{T P}$ & $\mathrm{NO}_{3}$ & $\begin{array}{c}\text { Oil \& } \\
\text { Grease }\end{array}$ & TKN & \begin{tabular}{|c|}
$\begin{array}{c}\text { Number } \\
\text { of cells or } \\
\text { eggs of } \\
\text { Nimatoda }\end{array}$ \\
\end{tabular} & $\begin{array}{l}\text { E.coli } \\
\text { count }\end{array}$ \\
\hline Unit & $\mathrm{mg} / \mathrm{l}$ & $\mathrm{mg} / \mathrm{l}$ & $\mathrm{mg} / \mathrm{l}$ & $\%$ & $\mathrm{mg} / \mathrm{l}$ & $\mathrm{mg} / \mathrm{l}$ & $\mathrm{mg} / \mathrm{l}$ & $\mathrm{mg} / \mathrm{l}$ & (Count/l) & $(100 / \mathrm{ml})$ \\
\hline $\begin{array}{c}\text { Raw } \\
\text { Greywater } \\
\text { average }\end{array}$ & $\begin{array}{c}126.67 \\
( \pm 20)\end{array}$ & $\begin{array}{c}470.17 \\
( \pm 44)\end{array}$ & $\begin{array}{c}346.17 \\
( \pm 44)\end{array}$ & $\begin{array}{l}20.87 \\
( \pm 1.8)\end{array}$ & $\begin{array}{c}9.91 \\
( \pm 1.1)\end{array}$ & $\begin{array}{c}2.67 \\
( \pm 0.20)\end{array}$ & $\begin{array}{l}124.83 \\
( \pm 23.2)\end{array}$ & $\begin{array}{c}45 \\
( \pm 5.9)\end{array}$ & --- & --- \\
\hline $\begin{array}{l}\text { Settling } \\
\text { effluent }\end{array}$ & $\begin{array}{l}44.92 \\
( \pm 16) \\
\end{array}$ & $\begin{array}{c}328.79 \\
( \pm 31) \\
\end{array}$ & \begin{tabular}{|c|}
$\begin{array}{c}247.93 \\
( \pm 30) \\
\end{array}$ \\
\end{tabular} & \begin{tabular}{|l|}
19.69 \\
$( \pm 1.8)$ \\
\end{tabular} & $\begin{array}{c}7.69 \\
( \pm 0.8) \\
\end{array}$ & 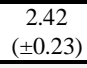 & \begin{tabular}{|c|}
79.09 \\
$( \pm 17.7)$ \\
\end{tabular} & \begin{tabular}{|l|}
38.33 \\
$( \pm 5.6)$ \\
\end{tabular} & --- & --- \\
\hline Settling ( $\mathrm{R} \%)$ & $64.54 \%$ & $30.07 \%$ & $28.38 \%$ & $5.65 \%$ & $22.40 \%$ & $9.36 \%$ & $36.64 \%$ & $14.82 \%$ & --- & --- \\
\hline \begin{tabular}{|c|}
$\begin{array}{c}\text { Horizontal } \\
\text { flow wetland } \\
\text { (effluent) }\end{array}$ \\
\end{tabular} & $\begin{array}{l}24.45 \\
( \pm 11)\end{array}$ & $\begin{array}{l}207.46 \\
( \pm 26.7)\end{array}$ & $\begin{array}{l}175.58 \\
( \pm 49.6)\end{array}$ & $\begin{array}{l}14.91 \\
( \pm 2.4)\end{array}$ & $\begin{array}{c}3.19 \\
( \pm 0.4)\end{array}$ & $\begin{array}{c}1.61 \\
( \pm 0.26)\end{array}$ & $\begin{array}{l}34.10 \\
( \pm 7.4)\end{array}$ & $\begin{array}{l}26.64 \\
( \pm 5.4)\end{array}$ & 1 & $<100$ \\
\hline $\begin{array}{c}\text { Horizontal } \\
\text { wetland (R } \\
\%)^{*}\end{array}$ & $80.70 \%$ & $55.87 \%$ & $49.28 \%$ & $28.56 \%$ & $67.81 \%$ & $39.70 \%$ & $72.68 \%$ & $40.80 \%$ & --- & --- \\
\hline $\begin{array}{c}\text { Vertical } \\
\text { wetland } \\
\text { (effluent) } \\
\end{array}$ & $\begin{array}{c}16.17 \\
( \pm 6)\end{array}$ & $\begin{array}{l}77.5 \\
( \pm 45)\end{array}$ & $\begin{array}{c}39.83 \\
( \pm 8)\end{array}$ & $\begin{array}{l}13.59 \\
( \pm 4.2)\end{array}$ & $\begin{array}{c}0.93 \\
( \pm 0.08)\end{array}$ & $\begin{array}{c}1.7 \\
( \pm 0.21)\end{array}$ & $\begin{array}{c}9.76 \\
( \pm 1.48)\end{array}$ & $\begin{array}{l}18.93 \\
( \pm 5.0)\end{array}$ & 1 & $<100$ \\
\hline $\begin{array}{c}\text { Vertical } \\
\text { wetland (R } \\
\%)\end{array}$ & $33.86 \%$ & $62.64 \%$ & $77.31 \%$ & $8.85 \%$ & $70.85 \%$ & $5.59 \%$ & $71.38 \%$ & $28.94 \%$ & --- & --- \\
\hline $\begin{array}{c}\text { Overall } \mathrm{R} \\
\text { \%**** }\end{array}$ & $87.23 \%$ & $83.52 \%$ & $88.49 \%$ & $34.88 \%$ & $90.61 \%$ & $36.33 \%$ & $92.18 \%$ & $57.93 \%$ & --- & -- \\
\hline $\begin{array}{l}\text { Permissible } \\
\text { limits } \\
2^{n d} \text { group for } \\
\text { (secondary } \\
\text { treatment)** }\end{array}$ & 40 & 80 & 40 & 20 & --- & --- & 10 & --- & 1 & 1000 \\
\hline
\end{tabular}

$\% \mathrm{R}=$ Percentage of removal, ${ }^{*}$ Horizontal wetland $(\mathrm{R} \%)=$ Percentage of total removal by degreasing/settling for $3.0 \mathrm{hr}$ followed by horizontal constructed wetland, ${ }^{* * *}$ Overall $\% \mathrm{R}=$ Percentage of total removal by degreasing/settling for $3.0 \mathrm{hr}$ followed by hybrid constructed wetland,

${ }^{* *}$ Egyptian Guideline = Egyptian code no. 501, 2005 for the reuse of treated wastewater in agriculture: Ministry of Housing, Utilities and New Communities.

\section{Conclusion and Economy of The System}

- The results of pilot plant indicated good quality of the treated final effluent.

- The advantage of $\mathrm{CW}_{\mathrm{s}}$ is that they are environmentally friendly, cost effective.

- $\mathrm{CW}$ for $24 \mathrm{hr}$ could achieve much higher removal rate of the pollution parameters. The characteristics of the final effluent could cope with the permissible level of $2^{\text {nd }}$ group "secondary wastewater treatment" for irrigation reuse according to Egyptian Guideline.

\section{Recommendations}

- Separation of municipal wastewater can be implemented in the remote and decentralized areas. 
- From the available data it can be recommended that the use of CW as a post treatment step after a settling tank is a promising technology for greywater reclamation and reuse.

- The CW requires large area of land for construction. Therefore, such system can be implemented in the remote and decentralized areas of Egypt as well as the Middle East and North African countries "MENA".

Acknowledgement: The authors wish to express their deep appreciation to the National Research Centre, Water Research \& Pollution Control Department for the facilities provided to the entire work of the present study. Sincere acknowledgement also goes to Ministry of Higher Education and Scientific Research of Iraq, Qadisiyah University for the financial support of Eng. Ahmed Al-Sulaiman.

\section{References}

1. Al Weshah, R., The role of UNESCO in sustainable water resources management in the Arab World. Desalination, 152, 1-13(2002).

2. Regelsberger, M., Baban, A., Bouselmi, L., Abdel Shafy, H. L. and El Hamouri, B., Zer0-M, sustainable concepts towards a Zer0-M outflow municipality. Desalination, 215, 64-72 (2007).

3. Lens, P., Zeeman, G. and Lettinga, G., Decentralised Sanitation and Reuse: Concepts, Systems and Implementation, IWA Publishing, UK, ISBN: 1-900222-477(2001).

4. Eriksson, E., Auffarth, K., Eilersen, A. M., Henze, M. and Ledin, A., Household chemicals and personal care products as sources for xenobiotic organic compounds in grey wastewater. Water $S A, 29$ (2), 135-146 (2003).

5. Melin, T., Jefferson, B., Bixio, D., Thoeye, C., Wilde, de, Koning J., van der Graaf and Wintgens, J., Membrane bioreactor technology for wastewater treatment and reuse. Desalination, 187, 271-282 (2006).

6. Merz, C., Scheumann, R., El Hamouri, B. and Kraume, M., Membrane bioreactor technology for the treatment of grey water from a sports and leisure club. Desalination, 215, 37-43(2007).

7. Abdel-Shafy, H. I. and El-Khateeb, M. A., Integration of degreasing tank and constructed wetland for the treatment of wastewater in Egypt. Journal Desalination and Water Treatment, Taylor and Francis Publisher, 51(16-18) (2013).

8. Masi, F., Conte, G. and Martinuzzi, N., Sustainable sanitation by constructed wetlands in the mediterranean countries: experiences in small/medium size communities and tourism facilities. In: I., Al Baz, R., Otterpohl, \& C., Wendland, "Ed." Efficient Management of Wastewater, Its Treatment and Reuse in Water Scarce Countries. Springer, NY, 125-138(2008). 
9. Friedler, E. and Galil, N.I., In: C., Maksimovich, D., Butler, F.A., Memon, (Ed.), "Advances in Water Supply Management". Balkema, the Netherlands, 535-544 (2003).

10. Jefferson, B., Judd, S. and Diaper, C., "Treatment methods for grey water", In: Decentralised Sanitation and Reuse: Concepts, Systems and Implementation; Lens, Zeeman, P., Lettinga, G., IWA: Wageningen, the Netherlands, 334-353 (2001).

11. Nolde, E., Greywater recycling systems in germany-results, experiences and guidelines. Water Science Technology, 51, 203-210 (2005).

12. Abdel-Shafy, H.I., El-Khateeb, M. A. and Shehata, M., Greywater treatment using different designs of sand filters. Journal Desalination and Water Treatment, Taylor and Francis Publisher, accepted for publication (2013).

13. Abdel-Shafy, H.I., El-Khateeb, M.A., Regelsberger, M., El-Sheikh, R. and Shehata, M., Integrated system for the treatment of blackwater and greywater via uasb and constructed wetland in Egypt. Desalination and Water Treatment, 8, 1-7 (2009).

14. Belmont, M. A., Ikonomou, M. and Metcalfe, C.D., Presence of nonylphenol ethoxylate surfactants in a watershed in central mexico and removal from domestic sewage in a treatment wetland. Environmental Toxicology Chemistry, 25, 29-35 (2006).

15. Abdel-Shafy, Hussein I., Al-Sulaiman, Ahmed, M. and Mansour, Mona S.M. Greywater treatment via hybrid integrated systems for unrestricted reuse in Egypt, $J$. Water Process Eng., 1, 101-107 (2014), http://dx.doi.org/ 10.1016/ j.jwpe. $\underline{2014.04 .001}$

16. Abdel-Shafy, H. I., Regelsberger, M., Masi, F., Platzer, Ch. and El-Khateeb, M. A., Constructed wetlands for the decentralized wastewater treatment and reuse in Egypt. Environmental Science Technology, Second NRC Conference, Egypt (2008).

17. APHA, AWWA and WEF, Standard Methods for the Examination of Water and Wastewater, $21^{\text {st }}$ ed., American Public Health Association, Washington, (2006), http://www.standardmethods.org/.

18. Crites, R. and Tchobanoglous, G., Small and Decentralized Wastewater Management System, WCB and McGraw-Hill. New York, USA (1998).

19. Vymazal, J., Horizontal sub-surface flow and hybrid constructed wetlands systems for wastewater treatment. Ecological Engineering, 25(5), 478-490 (2005).

20. Abdel-Shafy, H.I., Al-Sulaiman, A.M., Galal El-Din, M.M. and Abdel-Halim, H.S., Greywater treatment via integration effective microorganisms constructed wetland. J. Engineering and Applied Science, 60, 497-516(2013).

21. Egyptian Code No. (501), "For the Reuse of Treated Wastewater in Agriculture: Ministry of Housing, Utilities and New Communities (2005).

(Received 23/12/2014; accepted 5/1/2015)

Egypt. J. Chem. 57, No. 5, 6 (2014) 


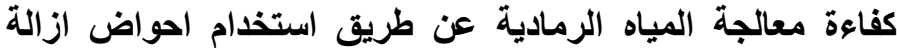 الدهون / الترسيب متبوعة بالار اضلى الرطبة الربة المزدوجة \\ حسين ابراهيم عبد الشافى وأحمد مكى السليمان

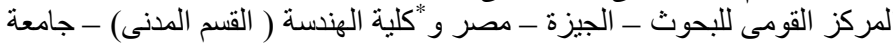

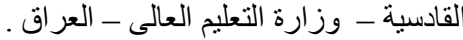

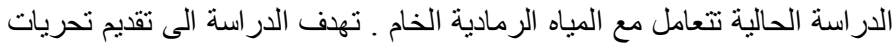

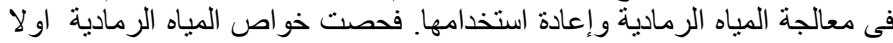

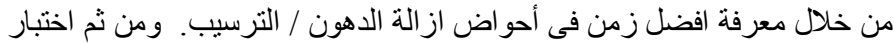

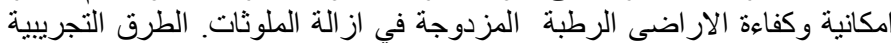

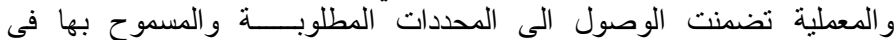

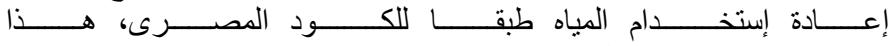

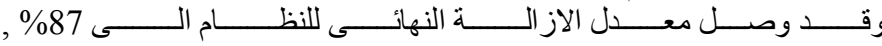

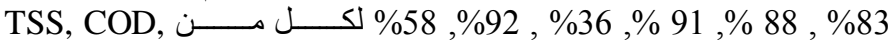

BOD 5 , TP, NO3, oil \& grease and TKN

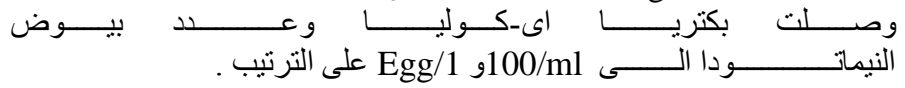

